DOI: $10.14451 / 2.124 .7$

\title{
ПРАВОВОЕ РЕГУЛИРОВАНИЕ ПРОГРАММНО-ЦЕЛЕВОГО ПОДХОДА В СИСТЕМЕ ГОСУДАРСТВЕННОГО УПРАВЛЕНИЯ В УСЛОВИЯХ СТРАТЕГИЧЕСКОГО РАЗВИТИЯ РОССИЙСКОЙ ФЕДЕРАЦИИ
}

\author{
(c) 2018 Щукина Татьяна Владимировна \\ доктор юридических наук, доцент, зав. кафедрой административного и финансового права \\ Липецкий филиал РАНХиГС \\ 398050, г. Липецк, ул. Интернациональная, д. 3 \\ профессор кафедры государственно-правовых дисциплин \\ Липецкий государственный педагогический университет \\ 398020, г. Липецк, ул. Ленина, д. 42 \\ E-mail: shukina-tv@mail.ru
}

Предметом настоящей статьи выступает исследование теоретических и практических представлений о правовом регулировании программно-целевого подхода в государственном управлении Российской Федерации; рассмотрение новых тенденций преобразования государственных программ в пилотные государственные программы, национальные проекты в условиях стратегического развития государства. Тема статьи отражает вопросы трансформации правового регулирования функции программирования; применения новых методов государственного управления, реализации проектной деятельности органов государственной власти. Целью настоящей статьи являются выявление на современном этапе специфики разработки и реализации государственных программ, их видов и структуры; особенностей реализации новых стратегий государственного развития в области национального проектирования. Методологию данной работы составили сравнительный, формально-юридический, аналитический методы. Результаты работы - это формулирование особенностей разработки и реализации стратегических документов. Область применения результатов работы включает в себя систему государственного и муниципального управления. Выводы исследования могут быть использованы для дальнейшего совершенствования правовой регламентации и практики применения функций стратегического управления.

Ключевые слова: государственная программа, государственная пилотная программа, национальный проект, структура государственной программы, правовое регулирование программно-целевого метода управления.

Правовая регламентация программно-целевого принципа управления была закреплена в Программе по повышению эффективности бюджетных расходов на период до 2012 года, утверждена распоряжением Правительства РФ N1101-р от 30 июня 2010 года [1]. В ней предполагалось в 2010-2012 годах внедрить программно-целевые принципы организации деятельности органов исполнительной власти и органов местного самоуправления к качестве одного из инструментов повышения эффективности бюджетных расходов. С точки зрения правового регулирования широкомасштабное внедрение программно-целевого управления во всех отраслях публичного управления и на всех уровнях властного воздействия стало осуществляться после упоминания об этом в Бюджетное послание Президента РФ Д.А. Медведева от 29 июня 2011 г. «О бюджетной политике в 20122014 годах». Подобное внедрение заключалось в разработке и принятии программных бюджетов и утверждении основных государственных программ. Основной целью встраивания государственных программ в стратегическое планирование является обеспечение эффективности бюджетных расходов [2]. Государственные программы становятся необходимым и современным инструментом системы публичного управления [3].

Государственные программы разрабатываются для достижения приоритетов и целей социально-экономического развития и обеспечения национальной безопасности РФ, определенных: а) в стратегии социально-экономического развития РФ, б) в отраслевых документах стратегического планирования РФ; в) в страте- 
гии пространственного развития РФ и основных направлениях деятельности Правительства РФ на соответствующий период, исходя из положений федеральных законов, решений Президента РФ и Правительства РФ.

Цели государственной программы должны соответствовать приоритетам государственной политики в сфере реализации государственной программы и определять конечные результаты реализации государственной программы. Цели государственной программы обладают определенными, измеримыми свойствами. Формулировка цели должна быть краткой и ясной и не должна содержать специальных терминов. Достижение цели обеспечивается за счет решения задач государственной программы. Задача государственной программы определяет результат реализации совокупности взаимосвязанных мероприятий или осуществления государственных функций в рамках достижения цели (целей) peaлизации государственной программы.

Государственные программы представляют собой определенную систему. Согласно Порядку разработки, реализации и оценки эффективности государственных программ Российской Федерации, утв. постановлением Правительства РФ от 2 августа 2010 г. N588 [4] государственная программа включает в себя федеральные целевые программы и подпрограммы, содержащие, в том числе, ведомственные целевые программы и основные мероприятия органов государственной власти. Подпрограммы направлены на достижение целей и решение задач в рамках государственной программы.

Перечень государственных программ утверждается Правительством РФ. Проект перечня государственных программ формируется Министерством экономического развития РФ совместно с Министерством финансов РФ: а) исходя из стратегии социально - экономического развития РФ и отраслевых документов стратегического планирования РФ, с учетом основных направлений деятельности Правительства РФ, б) на основании положений федеральных законов, предусматривающих реализацию государственных программ, а также во исполнение решений Президента РФ и Правительства РФ.

Перечень государственных программ содержит наименования государственных программ и их ответственных исполнителей. Особый порядок разработки, реализации и оценки эффективности государственных программ распространяется на программу вооружения и программы РФ: «Развитие здравоохранения», «Развитие образования», «Обеспечение доступным и комфортным жильем и коммунальными услугами граждан Российской Федерации», «Развитие транспортной системы», «Государственная программа развития сельского хозяйства и регулирования рынков сельскохозяйственной продукции, сырья и продовольствия на 20132020 годы». Ранее эти программы реализовывались в рамках федеральных целевых программ. С 2018 года они погружены в действие пилотных государственных программ, а выполнение семи федеральных целевых программ прекращено.

Кроме того, разработка, реализация и изменение государственных программ в части их основных мероприятий (подпрограмм), входящих в состав утвержденных приоритетных проектов (программ), осуществляются с учетом Положения «Об организации проектной деятельности в Правительстве Российской Федерации» [5]. При формировании государственных программ учитываются цели, задачи и мероприятия приоритетных национальных проектов, реализуемых в соответствующих сферах.

Распространение принципов проектного управления на пилотные государственные программы потребовало принятия новых бюджетных решений, по новым правилам, т.е. привязки бюджетных расходов к достижению конкретных целей. Федеральными органами исполнительной власти вначале 2018 года была проведена работа по ранжированию проектов (программ), которые подлежат обновленному бюджетированию. Необходимости в дополнительном финансировании не выявлено. Особое внимание в рамках проектного управления уделяется Правительством РФ порядку реализации межпрограммных проектов.

Принципы разработки и реализации государственных программ были закреплены и в распоряжении Правительства РФ № 1101-р от 30 июня 2010 года, и в Методических указаниях по разработке и реализации государственных программ Российской Федерации [6]. Постановление Правительства РФ от 19 апреля 2005 года N239 «Об утверждении Положения о разработке, утверждении и реализации ведомственных целевых программ» [7] устанавливает особенности процедуры подготовки и реализации ведомственных целевых программ, а также специфику их структуры и содержания. Ведомственная целевая 
программа взаимосвязана с соответствующей государственной программой как частное и целое; она является эффективным инструментом федеральных органов исполнительной власти по решению актуальных задач в конкретной сфере публичного управления; и предназначена для оптимизации расходов федерального бюджета. Ведомственная целевая программа - это нормативный правовой акт, направленный на осуществление федеральными органами исполнительной власти, иными федеральными государственными органами и организациями, являющимися главными распорядителями бюджетных средств.

Особый порядок разработки, реализации и оценки эффективности распространяется на отдельные государственные программы РФ - nuлотные государственные программы, которые взаимосвязаны с реализацией национальных приоритетных проектов (программ), направленных на стратегическое развитие Российской Федерации [8]. К пилотным государственным программам РФ относятся пять ранее указанных государственных программ.

Под пилотной государственной программой понимается нормативный правовой акт, предусматривающий реализацию комплекса мероприятий, направленных на достижение определенных документами стратегического планирования целей государственной политики в соответствующей сфере, на принципах проектного управления. Пилотная государственная программа утверждается нормативным правовым актом Правительства РФ. Пилотные государственные программы предназначены для снижения бюрократических барьеров в процессе разработки и реализации документов, направленных на решение наиболее важных задач государства, уменьшения документооборота на бумажных носителях и достижения целей стратегического развития РФ наиболее оптимальными способами. Этому должны способствовать принципы проектного управления, которые полностью распространяются на вышеуказанные государственные программы. В этих целях была систематизирована структура пилотной государственной программы, комбинировано ее содержание и упрощено целеполагание. Проекты (программы), отдельные мероприятия межпрограммных проектов (программ) и ведомственные целевые программы группируются по направлениям реализации (подпрограм- мам) пилотной государственной программы.

Пилотная государственная программа состоит из проектной и процессной частей. В проектную часть пилотной государственной программы включаются приоритетные проекты (программы), ведомственные проекты (программы), межпрограммные проекты (программы) и отдельные мероприятия межпрограммных проектов (программ). На указанные проекты распространяется Положение «Об организации проектной деятельности в Правительстве Российской Федерации», утвержденное постановлением Правительства РФ от 15 октября 2016 г. N1050.

Процессная часть пилотной государственной программы содержит ведомственные целевые программы и при необходимости отдельные мероприятия, направленные на финансовое обеспечение деятельности центральных аппаратов федеральных органов исполнительной власти и их территориальных органов. На указанные целевые ведомственные программы распространяется Положение «О разработке, утверждении и реализации ведомственных целевых программ», утвержденное постановлением Правительства РФ от 19 апреля 2005 г. N239

В пилотной государственной программе допускается формулирование всего пяти целей и не более, что в определенной мере сокращает объем программы и способствует конкретизации необходимых для реализации мероприятий. Цели пилотной государственной программы должны соответствовать критериям конкретности, измеримости, достижимости, актуальности и ограниченности во времени. Цели пилотной государственной программы формулируются в виде целевых значений показателей (индикаторов) социально - экономического развития Российской Федерации и обеспечения национальной безопасности. Включаемые в пилотную государственную программу проекты (программы) и ведомственные целевые программы должны быть направлены на достижение целей пилотной государственной программы и в совокупности обеспечивать их достижение. Соответствующая оценка обеспеченности целей пилотных государственных программ проектами (программами) и ведомственными целевыми программами осуществляется в ходе ранжирования проектов (программ) и ведомственных целевых программ.

В соответствии с Правилами формирования 
и реализации федеральной адресной инвестиционной программы, утвержденными постановлением Правительства РФ от 13 сентября 2010 г. N716 утверждается порядок ее формирования и реализации, а также формирования и ведения информационного ресурса федеральной адресной инвестиционной программы. Под федеральной адресной инвестиционной программой понимается документ, устанавливающий распределение предусмотренных в федеральном законе о федеральном бюджете на очередной финансовый год и плановый период бюджетных ассигнований. За 2017 год по данным Правительства РФ общий объём бюджетных ассигнований на реализацию Федеральной адресной инвестиционной программы составил (с учётом гособоронзаказа) 761,6 млрд.рублей [9]. Но есть и проблемы, связанные с реализацией ФАИП. В 2017 году в установленные сроки было завершено строительство 281 из 408 объектов, подлежащих вводу в эксплуатацию. Это свидетельствует о росте объемов незавершенного строительства по ФАИП [10].
В 2017 году было реализовано 33 федеральные целевые программы и одна Федеральная адресная инвестиционная программа. На реализацию целевых программ было направлено более 820 млрд. рублей. Самыми высокоэффективными признаны три программы: по повышению безопасности дорожного движения, по развитию сельских территорий и по строительству жилья [11]. Между тем, существуют определенные проблемы, возникающие в ходе разработки и реализации государственных программ. Например, в 2018 году увеличились объемы финансирования многих государственных программ, а уточнение их показателей отсутствовало; по некоторым государственным программам были разногласия между субъектами их реализации [12]. По данным исследования Ноженко Д.Ю. отметим, что «в конце 2016 начале 2017 годов регионами реализовалось порядка 1850 государственных программ, что в среднем составило порядка 22 государственные программы в одном субъекте» [13].

\section{Библиографический список}

1. Программа по повышению эффективности бюджетных расходов на период до 2012 года, утв.распоряжением Правительства РФ N1101-р от 30 июня 2010 года // Собр. законодательства Рос. Федерации. 2010. 2․ Ст. 3720 .

2. Ноженко Д.Ю. Государственные программы как инструмент стратегического управления: межрегиональный анализ // Вопросы управления. Режим доступа. URL. http://vestnik.uapa.ru/ru /issue/2016/04 /02/

3. Порядок разработки, реализации и оценки эффективности государственных программ Российской Федерации, утв. постановлением Правительства РФ от 2 августа 2010 г. N588 (с изм. от 23 августа 2018 г.) // Собр. законодательства Рос. Федерации. 2010. N32. Ст. 4329.

4. Порядок разработки, реализации и оценки эффективности государственных программ Российской Федерации, утв. постановлением Правительства РФ от 2 августа 2010 г. N588 (с изм. от 23 августа 2018 г.) // Собр. законодательства Рос. Федерации. 2010. N32. Ст. 4329.

5. Об организации проектной деятельности в Правительстве Российской Федерации: положение, утв. постановлением Правительства РФ от 15 октября 2016 года N1050 «Об организации проектной деятельности в Правительстве Российской Федерации» // Собр. законодательства Рос. Федерации. 2016. N43. Ст. 6028.

6. Методические указания по разработке и реализации государственных программ Российской Федерации, утвержденные приказом Министерства экономического развития РФ от 26 декабря 2012 г. N817 «Об утверждении Методических указаний по разработке и реализации государственных программ Российской Федерации». Режим доступа: URL: официальный интернет-портал правовой информации. www.pravo.gov. $\mathrm{ru}$

7. Об утверждении Положения о разработке, утверждении и реализации ведомственных целевых программ: постановление Правительства РФ от 19 апреля 2005 г. N239 (с изм. от 23 февраля 2018 г.) // Собр. законодательства Рос. Федерации. 2005. N17. Ст. 1571.

8. О разработке, реализации и об оценке эффективности отдельных государственных программ Российской Федерации: постановление Правительства РФ от 12 октября 2017 г. N1242 // Собр. законодательства Рос. Федерации. 2017. N43 (часть II). Ст. 6323.

9. Материалы к заседанию Правительства РФ 22 марта 2018 года. Режим доступа: URL. http://government.ru/ news/31788/

10. Там же. 
11. Там же.

12. Там же.

13. Ноженко Д.Ю. Государственные программы как инструмент стратегического управления: межрегиональный анализ // Вопросы управления. Режим доступа. URL. http://vestnik.uapa.ru/ru/issue/2016/04/02/

Поступила в редакцию 21.10.2018 